\title{
Field comparison of transpiration, stomatal conductance and vulnerability to cavitation of Quercus petraea and Quercus robur under water stress
}

\author{
N Bréda, H Cochard, E Dreyer, A Granier *
}

INRA, Laboratoire de Bioclimatologie et Écophysiologie, Champenoux, F54280 Seichamps, France

(Received 6 January 1993; accepted 2 June 1993)

\begin{abstract}
Summary - Water relations were analysed in adult oaks (Quercus petraea and $Q$ robur) during a period of water shortage in a simplified lysimeter. Sap flux densities and stomatal conductance were reduced by $\approx 70 \%$ at maximal drought intensity. Predawn leaf water potential then ranged from -1.7 to $-2.0 \mathrm{MPa}$. The slightly lower transpiration observed in pedunculate oaks could be ascribed to their smaller crown development. Nevertheless, no significant difference in stomatal conductance could be observed between the two species. They also had the same percent loss of conductivity $(\approx 80 \%)$ in petioles at maximal drought intensity when midday leaf water potential had dropped to $\approx-3.0$ $\mathrm{MPa}$. Finally, good agreement was found between observed losses of hydraulic conductivity during in situ dehydration and the vulnerability curves obtained under laboratory conditions. The shifts in maximal conductivity observed in some droughted trees probably accentuated discrepancies between field and laboratory data. However, a correction procedure helped overcome these artifacts.
\end{abstract}

drought / xylem / cavitation / stomatal conductance / sap flux / Quercus petraea / Quercus robur

Résumé - Comparaison en conditions naturelles de la transpiration, de la conductance stomatique et de la vulnérabilité à la cavitation de Quercus robur et $Q$ petraea soumis à un stress hydrique en forêt de Champenoux (France). L'étude compare le comportement hydrique de chênes sessiles (Quercus petraea) et pédonculés ( $Q$ robur) adultes en conditions de dessèchement du sol. Les mesures de flux de sève et de conductance stomatique ont montré une diminution de 65 à $70 \%$ de ces paramètres au maximum de la sécheresse. Les potentiels de base atteints

\footnotetext{
* Correspondence and reprints.

Abbreviations: $F_{\mathrm{d}}$ : sap flux density $\left(\mathrm{dm}^{3} \cdot \mathrm{dm}^{-2} \cdot \mathrm{h}^{-1}\right) ; g_{\mathrm{s}}$ : midday stomatal conductance to water vapor $\left(\mathrm{cm} \cdot \mathrm{s}^{-1}\right) ; k_{i}$ : initial hydraulic conductivity of petioles $\left(\mathrm{kg} \cdot \mathrm{m} \cdot \mathrm{s}^{-1} \cdot \mathrm{MPa}-1\right) ; K_{\text {max }}$ : maximal hydraulic conductivity of petioles after 2 flushes at high pressure $\left(\mathrm{kg} \cdot \mathrm{m} \cdot \mathrm{s}^{-1} \cdot \mathrm{MPa}^{-1}\right) ; \psi_{\mathrm{wm}}$ : midday leaf water potential (MPa); $\psi_{\mathrm{wp}}$ : predawn leaf water potential (MPa).
} 
étaient alors compris entre $-1,7$ et $-2,0 \mathrm{MPa}$. Une transpiration légèrement plus faible observée pour le chêne pédonculé a été interprétée comme résultant de différences dans le statut social des 2 espèces. Toutefois, aucune différence significative de conductance stomatique n'a pu être mise en évidence entre les 2 espèces, qui apparaissent toutes 2 comme assez tolérantes à la sécheresse. Au plus fort de la sécheresse, les 2 espèces ont montré des pourcentages d'embolie de l'ordre de 70 à $80 \%$ dans leurs pétioles, alors que le potentiel hydrique foliaire minimum atteignait $-3,0 \mathrm{MPa}$. Enfin, une bonne concordance entre les mesures de perte de conductivité réalisées lors du dessèchement progressif in situ, et les courbes de vulnérabilité établies au laboratoire a été mise en évidence. Cependant, des dérives de conductance maximale en cours de sécheresse ont été à l'origine de certaines des différences observées. Dans ce cas, une procédure de correction du pourcentage d'embolie a permis de contrebalancer cet effet.

chêne sessile / chêne pédonculé / flux de sève / cavitation / sécheresse / conductance stomatique / xylème

\section{INTRODUCTION}

The distribution of species in the genus Quercus (oaks) depends partly on water availability. Large differences in drought tolerance are found among oak species. Among western European oak species, sessile oak (Quercus petraea) is known to be more tolerant to water shortage and to require less fertile soils than pedunculate oak (Quercus robur) (Becker et al, 1982).

In the northern half of France, deep soils with high fertility and periods of waterlogging, due to the presence of a clay layer, are common (Pardé, 1942). On these sites, sessile and pedunculate oaks can grow together. They are found in mixed stands comprised of small groups of each species rather than being intermixed. Becker (1986) showed differences in vigor and growth rates between species, with sessile having a clear advantage over pedunculate oak. This observation is also confirmed by forest managers. When both $Q$ robur and $Q$ petraea grow together in the same site, sessile oak is always taller, larger in diameter and healthier than pedunculate oak. Some forest management texts even suggest replacing the latter by the former whenever possible (Poskin, 1934).
Furthermore, periods of oak decline and dieback occurred following the 1976 drought. The drought affected mainly pedunculate oaks (Becker and Lévy, 1982). Apparently, this species appears to be more sensitive to dry periods. On the other hand, we concluded recently (Bréda et al, 1993) that sessile oak was rather droughttolerant, as are most North American oaks (Abrams, 1990).

An explanation for these frequently observed differences in the ecological requirements of both species may be related to water transport efficiency, and to possible involvement of cavitation and embolism in stress reactions. Cochard et al (1992) showed that $Q$ robur was more prone to water-stress-induced embolism than $Q$ petraea. However our measurements were made on branches rapidly dehydrated under laboratory conditions. These observations have to be confirmed with adult trees under natural conditions, and the importance of cavitation in drought reactions of trees in the stand has to be assessed (Cochard et al, 1992).

This paper presents a comparative analysis of water relations between trees of these 2 species growing in a natural mixed stand. Sensitivity of mature trees to drought was assessed using an imposed water shortage in a simplified lysimeter. 
Seasonal time-course of water relations of both watered and droughted trees was monitored and analysed.

\section{MATERIAL AND METHODS}

\section{Experimental plots}

Effects of water stress on $Q$ petraea and $Q$ robur were compared in 2 groups of 8 trees ( 4 of each species) in a 30-yr old, 16-m high mixed stand in the Forest of Champenoux, near Nancy, France $\left(48^{\circ} 44 \mathrm{~N}, 6^{\circ} 14 \mathrm{E}\right.$, elevation: $\left.237 \mathrm{~m}\right)$. Two scaffolding towers allowed measurements in the crowns, each giving access to 4 trees of each species. These experimental plots have been extensively described elsewhere (Bréda et al, 1993) and consist of a control plot and a dry plot. The dry plot consists of a $5 \times 5 \mathrm{~m}$ square that includes 17 trees and is surrounded by a 1.4-m deep trench. A water-tight roof covered the soil below the crowns. The comparative study was carried out during 2 successive seasons:

- During 1991, the control plots was left under natural conditions during the first part of the season and watered by manual irrigation at the end of August (d 241, 2 irrigations of $60 \mathrm{~mm}$ each). In the dry plot, water supply was withheld since end of June (day 170). Unfortunately, a late frost in spring immediately after leaf emergence completely killed the bursting buds and induced a 3wh delay in leaf flushing. A limited rehydration occurred in this treatment as a consequence of leaks which occurred during a thunderstorm (d 278, Oct 4). The whole lysimeter was completely rewatered in late autum, after all the leaves had fallen (d 317, Nov 13), by manually adding $90 \mathrm{~mm}$ water and removing the roof.

- During winter 1991-1992, natural rainfall completely resaturated the soil.

- During 1992, the control plot was kept well watered by natural and manual irrigation during the measurement period. The lysimeter was covered before bud-break (d 60, end of February). The rewatering occurred on October 8 (d 282), before litter-fall, by applying $150 \mathrm{~mm}$ water.

The number of trees studied in each plot has been presented in table $\mathrm{I}$.
Table I. Number of trees measured for both species (Quercus petraea and Quercus robur) in each treatment during 1991 and 1992 experiments for potentials, stomatal conductance and sap flux density measurements.

\begin{tabular}{cccccc}
\hline & \multicolumn{2}{c}{ Control } & & \multicolumn{2}{c}{ Dry } \\
\cline { 5 - 6 } Q petraea & Q robur & & Q petraea Q robur \\
\hline 1991 & 2 & 2 & & 3 & 3 \\
1992 & 1 & 1 & & 2 & 2 \\
\hline
\end{tabular}

\section{Measurements}

Leaf water potential was measured weekly on 2 leaves of each study tree using a pressure chamber. Leaves were sampled in the upper third of the crown just prior to dawn (predawn leaf water potential, $\psi_{\mathrm{wp}}$ ) and at $1 \mathrm{pm}$ solar time during sunny days (midday leaf water potential, $\left.\psi_{\mathrm{wm}}\right)$. Predawn leaf water potential $\left(\psi_{\mathrm{wp}}\right)$ was used as an index of mean soil water in the root zone.

Sap flow was monitored on all study trees using a continuously heated radial flowmeter all over the growing season (Granier, 1985, 1987). This device allows measurement of sap flux density $\left(F d, \mathrm{dm}^{3} \cdot \mathrm{dm}^{-2} \cdot \mathrm{h}^{-1}\right)$ along a radial axis ( $2 \mathrm{~cm}$ long) in the xylem. Total sap flux $\left(\mathrm{dm}^{3} \cdot \mathrm{h}^{-1}\right)$ was calculated by multiplying sap flux density $\left(F_{\mathrm{d}}\right)$ by the sapwood cross-section at the same height in the trunk. Stand transpiration was computed from sap flow measurements by taking into account the statistical weight of the sampled trees in the stand. This experimental procedure has been described by Bréda et al (1993).

Midday stomatal conductance of water vapor $g_{\mathrm{s}}$ was measured between 11 and 12 am solar time each week with a Li-Cor 1600 porometer (Lincoln, NE, USA) on 5 to 10 sun-exposed leaves on different branches from the upper half of the crown.

Soil water content was measured weekly in 8 ( 3 in the control plot and 5 in the dry one) $1.6-\mathrm{m}$ long deep aluminium access tubes via a neutron probe (NEA, Denmark). 
Assessment of embolism for the 2 oak species was made on excised petioles. Two or 32 yr-old branches were cut from the upper canopy of each study tree during the early morning and brought into the laboratory. All measurements were performed within $4 \mathrm{~h}$ on 5 to 8 petioles recut under water (Cochard et al, 1992). Hydraulic conductivity was measured on 2 -cm long samples using the technique described by Sperry et al (1988) and Cochard and Tyree (1990). Acidified and de-aerated water was forced through the samples at a low pressure $(7 \mathrm{kPa})$, the flow measured with a balance, and the initial conductivity $\left(K_{\mathrm{i}}\right)$ calculated from the flow/pressure ratio. Two successive periods of overpressure flushing ( $0.1 \mathrm{MPa}$, over a $20-\mathrm{min}$ period) allowed the embolized vessels to refill. The resulting conductivity (maximal conductivity) was calculated as previously described. The ratio between initial $\left(K_{\mathrm{i}}\right)$ and maximal conductivity $\left(K_{\max }\right)$ yields the loss of conductivity according to:

$$
\% \text { loss of conductivity }=1-\left(K_{\mathrm{i}} / K_{\max }\right)
$$

\section{RESULTS}

\section{Time-course of leaf water potential}

Figure 1 shows the seasonal time-course of predawn and midday leaf water potentials $\left(\psi_{w p}\right.$ and $\left.\psi_{w m}\right)$ for each treatment and species during the 2 study seasons. During the first part of 1991 (fig 1a), and until the irrigation of the control plot (d 241), there was no significant difference between species in the control plot, neither for predawn nor for midday leaf water potentials. $\psi_{\text {wp }}$ of control trees showed a strong decline from -0.5 to $-1.3 \mathrm{MPa}$ between the first part of the season until the end of August (d 240). In fact, control trees were water-stressed for a month till the rewatering on $\mathrm{d} 240$.

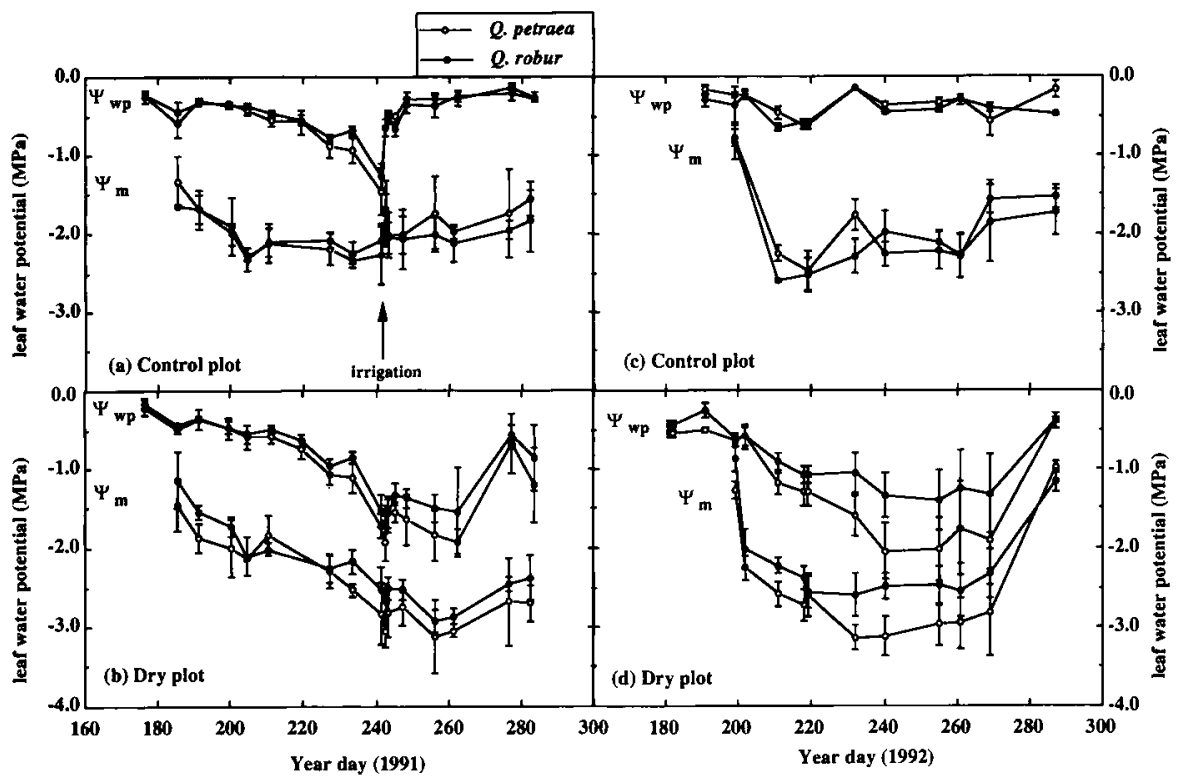

Fig 1. Seasonal time-course of predawn $\left(\psi_{\mathrm{wp}}\right)$ and midday $\left(\psi_{\mathrm{m}}\right)$ leaf water potential of control (a: 1991, c: 1992) and droughted trees (b: 1991, d: 1992) of Quercus petraea (open symbols) and $Q$ robur (filled symbols). Each point represents the mean value ( \pm SD) for 4 leaves from 2 dominant trees in the control plot, and 6 leaves from 3 dominant trees in the dry plot. Irrigation in the control plot occurred on d 241-1991 (August 29). 
In the dry plot (fig 1b), $\psi_{\text {wm }}$ was initially slightly higher in pedunculate oak than in sessile oak (d 180-210). The difference between $\psi_{\mathrm{wp}}$ and $\psi_{\mathrm{wm}}\left(\Delta \psi_{\mathrm{w}}\right)$ increased more gradually in the former than in the latter species. This was related to the delay in leaf area index development in the former species, due to a higher sensitivity to spring-frost. Later on, drought induced a gradual and parallel decline in $\psi_{w p}$ and $\psi_{w m}$ until September 20 (d 263). On September 23 (d 266), a thunderstorm promoted a non-controlled and deep rewatering leading to an increase of leaf water potential. During the greatest periods of stress, values of $\psi_{w p}$ and $\psi_{w m}$ were slightly but consistently lower in sessile than in pedunculate oaks. A similar seasonal variation was observed during 1992, except that, as control trees were kept well watered, $\psi_{\text {wp }}$ never dropped below -0.60 MPa (fig 1c). During 1992, the difference between sessile and pedunculate droughted trees were greater and significant for $\psi_{\mathrm{wp}}$ and $\psi_{\mathrm{wm}}$ (fig 1d).

\section{Effects of restricted water supply on sap flux density}

The daily time-course of sap flux density $\left(F_{\mathrm{d}}\right)$ in droughted trees did not display interspecific difference at the beginning of the drought period (d 210, July 29 1991; 3 trees per species, fig 2). These values were not significantly different from the mean of control trees. Nevertheless, the 2 smallest trees (one of each species) showed a lower $F_{\mathrm{d}}$ that was already observed on other suppressed trees (Bréda et al, 1993). On d 262 (September 19), drought induced a strong decline in $F_{\mathrm{d}}$ for both species. This decline appeared to be greater for the pedunculate oaks, despite their slightly higher predawn leaf water potential $\left(\psi_{\mathrm{wp}}=-1.54 \mathrm{MPa}\right)$, compared to sessile oaks ( $\left.\psi_{\mathrm{wp}}=-1.75 \mathrm{MPa}\right)$. Drought

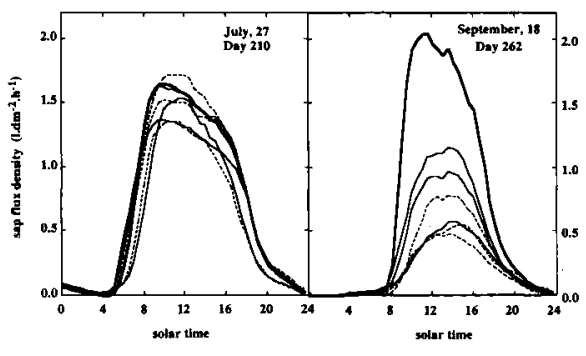

Fig 2. Diurnal time-course of individual xylem sap flux density measured on 3 droughted trees of $Q$ petraea (line) and $Q$ robur (dotted line) and mean sap flux calculated on 4 control trees (mean value for both species) (bold line) for 2 stress intensities: D 210: $\psi_{w p}=-0.5 \mathrm{MPa}$ for both treatments; D 262: control plot: $\psi_{\mathrm{wp}}=-0.3$ $\mathrm{MPa}$; dry plot: $\psi_{\mathrm{wp}}=-1.7 \mathrm{Mpa}$.

increased the variability in $F_{\mathrm{d}}$ within each species. Again, $F_{\mathrm{d}}$ was lower in the 2 smallest trees.

Seasonal variations of the mean daily sap flow of the 3 dry pedunculate and 3 dry sessile oaks, averaged over 10-d periods, have been shown in figure 3. A strong drought-related decrease in total transpiration occurred in both species, as compared

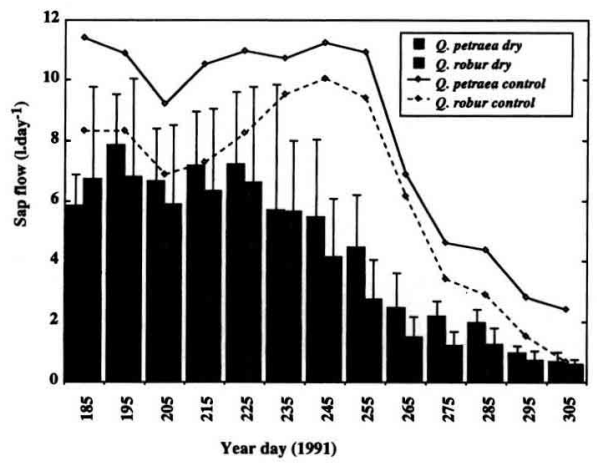

Fig 3. Seasonal time-course of the mean daily sap flow averaged over a 10-d period $\left(1 \cdot \mathrm{d}^{-1}\right)$ for $Q$ petraea (black) and $Q$ robur (gray) in the dry and control treatments. Vertical bars indicate SD. 
with control trees. During stress, sessile oaks maintained slightly higher sap flows than pedunculate oaks. This difference, even if not always statistically significant because of high within-tree variability, was nevertheless maintained during the whole period. Variations in soil water content were computed during the 2 seasons. The maximum extracted water in the lysimeter was $141 \mathrm{~mm}$ during 1991 and $148 \mathrm{~mm}$ during 1992. Soil water depletion as detected in the vicinity of root systems of both species to a $1.60-\mathrm{m}$ depth was rather similar (data not shown). Nevertheless, water content profites at the end of the dry period showed that extraction had occurred in even deeper soil layers near sessile oak roots.

\section{Stomatal conductance}

Seasonal time-course of midday stomatal conductance $g_{\mathrm{s}}$ (fig 4) displayed large vari- ations during 1991 and 1992. No difference appeared at the beginning of the 2 seasons between dry and control plots and between each species. $g_{\mathrm{s}}$ increased gradually in both species with a large variability between leaves. This may be ascribed to leaf maturation. Maximal values were $\approx 0.6$ $\mathrm{cm} \cdot \mathrm{s}^{-1}$ for both species during 1991 (fig $4 a, b)$ and somewhat higher during 1992 $\left(0.8 \mathrm{~cm} \cdot \mathrm{s}^{-1}\right.$, fig $\left.4 \mathrm{c}, \mathrm{d}\right)$. Higher maximal values of $g_{\mathrm{s}}$ measured in 1992 may be ascribed to the better irrigation of the control plot during this year. A strong decline in $g_{\mathrm{s}}$ was observed in the control trees (fig $4 a, b)$, which was reversed after rewatering by irrigation ( $\mathrm{d} 240$ ) and was followed by a relative stability during late summer.

In contrast, trees in the stressed plot during 1991 showed much lower values after $d 240 . g_{\mathrm{s}}$ stabilised around minimal values of $0.05 \mathrm{~cm} \cdot \mathrm{s}^{-1}$ until accidental and partial rewatering (d 268) occurred. It increased slightly later on. This increase

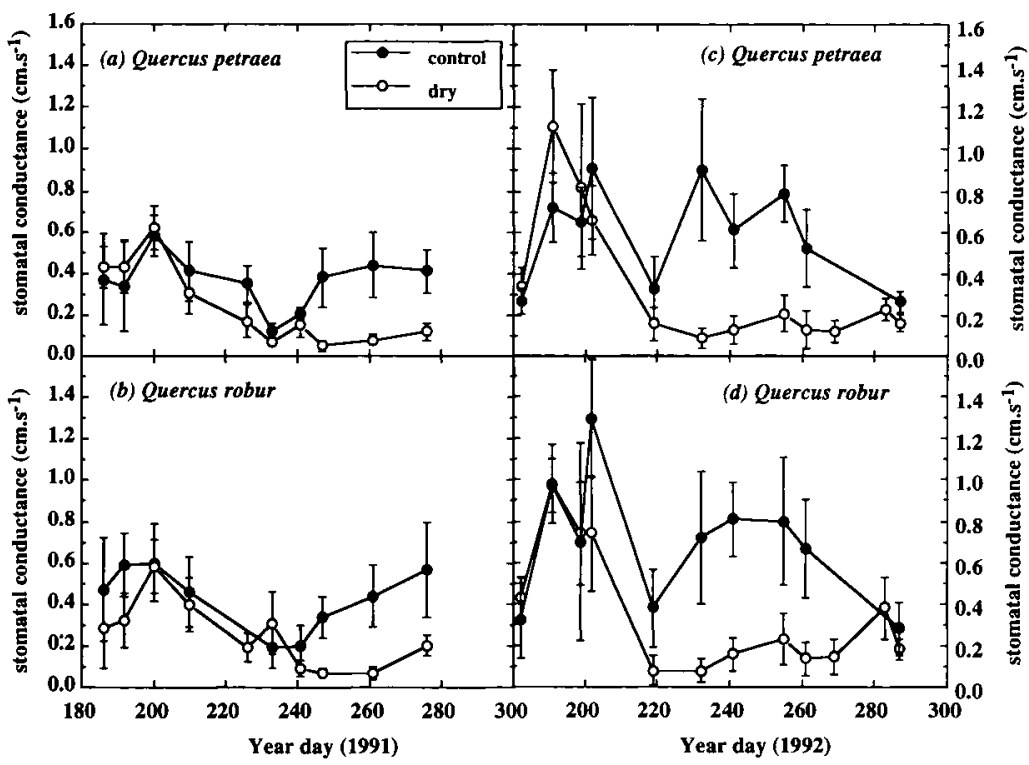

Fig 4. Seasonal time-course of mean midday stomatal conductance $( \pm S D$ ) measured on 10 sunexposed leaves of the upper canopy of control (black symbols) and droughted (open symbois) trees of $Q$ petraea (a: 1991, c: 1992) and $Q$ robur (b: 1991, d: 1992). Control trees were irrigated on d 241, 1991. 
was larger in $Q$ robur. During 1992, minimal values were of the same magnitude $\left(<0.1 \mathrm{~cm} \cdot \mathrm{s}^{-1}\right)$ but were reached earlier $\mathrm{d}$ 220) for $Q$ robur and $Q$ petraea (fig $4 c, d$ ).

A general plot of $g_{\mathrm{S}}$ (values of 1991 and 1992) as a function of $\psi_{w p}$ is presented in figure 5. For a statistical analysis of interspecific differences, data were separated into 2 classes according to their value of $\psi_{\text {wp }}$ (below and above $-0.6 \mathrm{MPa}$ ). Differences between species were tested ( $t$-test) within each class. Neither mean values nor regressions (linear model for $g_{\mathrm{s}}$ ) were significantly different between species. A sharp decrease associated with a large dispersion for predawn leaf water potential values ranging between -0.25 and -0.6 $\mathrm{MPa}$ was observed. Between -0.6 and $-2.0 \mathrm{MPa}$ the decrease in $g_{\mathrm{s}}$ was more gradual. Under most severe water stress conditions, stomatal conductance still remained at significant and constant levels of about $0.10 \mathrm{~cm} \cdot \mathrm{s}^{-1}$, thereby allowing significant rates of leaf transpiration to continue.

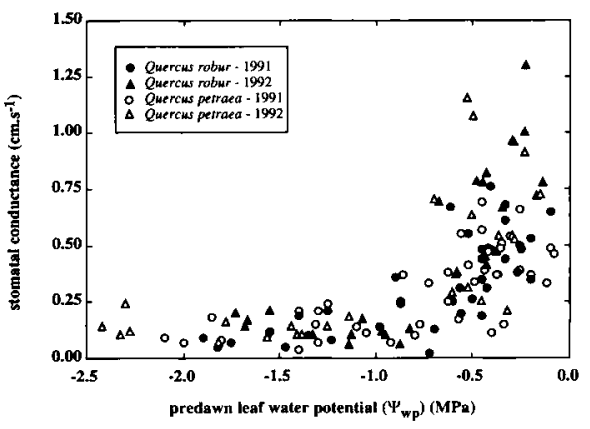

Fig 5. Midday stomatal conductance $\left(g_{\mathrm{s}}\right.$ for $Q$ robur (black symbols) and $Q$ petraea (open symbols) plotted against predawn leaf water potential $\left(\psi_{\text {wp }}\right)$. Data for years 1991 (circles) and 1992 (triangles) were pooled for each species. Each value is a mean of 10 replicates. Means of gs for $Q$ robur and $Q$ petraea were 0.56 and 0.50 $\mathrm{cm} \cdot \mathrm{s}^{-1}$ (NS) above $\psi_{\mathrm{wp}}=-0.6 \mathrm{MPa}$, and 0.19 and $0.17 \mathrm{~cm} \cdot \mathrm{s}^{-1}$ (NS) below this threshold, respectively.

\section{Development of embolism in the field}

Figure 6 shows an example of the seasonal progession of embolism on petioles of one dominant tree of each species. A significant reduction in conductivity was observed in petioles after the first measurement performed in late spring 1991, when drought had not yet begun. During 1991 (fig 6a), embolism increased after the date when $\psi_{\text {wp }}$ was $-1.8 \mathrm{MPa}$ for both trees, at which time $\psi_{\mathrm{wm}}$ was $-3.3 \mathrm{MPa}$ for $Q$ petraea and $-2.6 \mathrm{MPa}$ for $Q$ robur. At this time, loss of conductivity reached $40 \%$ for $Q$ petraea and $10 \%$ for $Q$ robur. During 1992 (fig 6b), embolism reached $80 \%$ for $Q$ petraea and $30 \%$ for $Q$ robur at maximum stress intensity. The same minimal values of $\psi_{w m}$ were observed during 1992 as well as during $1991(-3.3$ and $-2.6 \mathrm{MPa}$

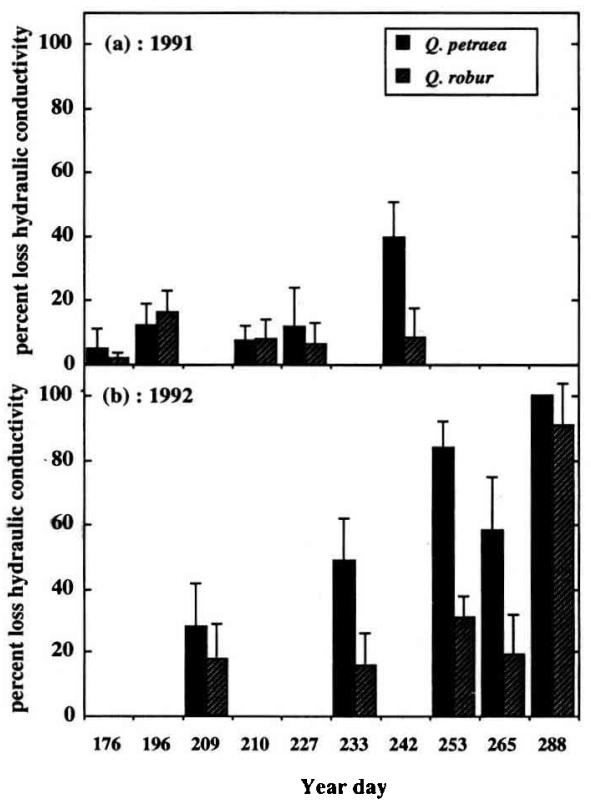

Fig 6. Seasonal progression of xylem embolism in petioles of both sessile (black) and pedunculate oaks (grey) in the droughted plot: (a): 1991; (b): 1992. Mean values of 5 to 8 replicates for 1 dominant trees of each species \pm SE. 
respectively for both species). We attribute the $100 \%$ loss of conductivity that occurred on $d 286$ in 1992 to the first frost event $\left(-2^{\circ} \mathrm{C}\right)$.

\section{In situ observed embolism as compared to vulnerability curves}

We plotted losses of hydraulic conductivity observed in situ during 1991 and 1992 on petioles against the minimum value of midday leaf water potential recorded prior to each estimate of embolism (fig 7). The resulting plot was compared with vulnerability curves obtained on excised branches dehydrating under laboratory conditions (Cochard et al, 1992). Despite a higher variability for in situ dehydration, we observed good agreement between both sets of results in sessile oak (fig 7a). However, in the case of pedunculate oak (fig $7 \mathrm{~b}$ ), the losses of conductivity measured on petioles in situ seemed to remain below the vulnerability curve between -2.5 and -3.0 MPa. But at the same time, during 1992 we observed a large decrease in the maximal hydraulic conductivity $K_{\max }$ for pedunculate oak in the dry plot from d 233 (August 20) on: $K_{\max }$ decreased from $6.6 \times$ $10^{-7}\left( \pm 5.3 \times 10^{-7}\right)$ to $3.5 \times 10^{-7}( \pm 3.3 \times$ $10^{-7}$ ) $\mathrm{kg} \cdot \mathrm{m} \cdot \mathrm{s}^{-1} \cdot \mathrm{MPa}^{-1}$ (in $1991, K_{\max }$ displayed a mean value of $6.1 \times 10^{-7} \pm 2.9 \times$ $10^{-7}$ ). Such a decrease was not observed in sessile oak, where $K_{\max }$ remained constant during the entire season $\left(11 \times 10^{-7} \pm\right.$ $\left.2.6 \times 10^{-7} \mathrm{~kg} \cdot \mathrm{m} \cdot \mathrm{s}^{-1} \cdot \mathrm{MPa}^{-1}\right)$. The technique used to restore maximal conductivity in the petioles did not fully resaturate the embolized vessels during late summer and led to a value of $K_{\max }$ which was significantly lower than the pre-stress maximal conductivity. We recalculated the percentage of embolism using the average values of $K_{\max }$ measured before the decrease began. As shown in figure 8 , corrected values of losses of hydraulic conductivity

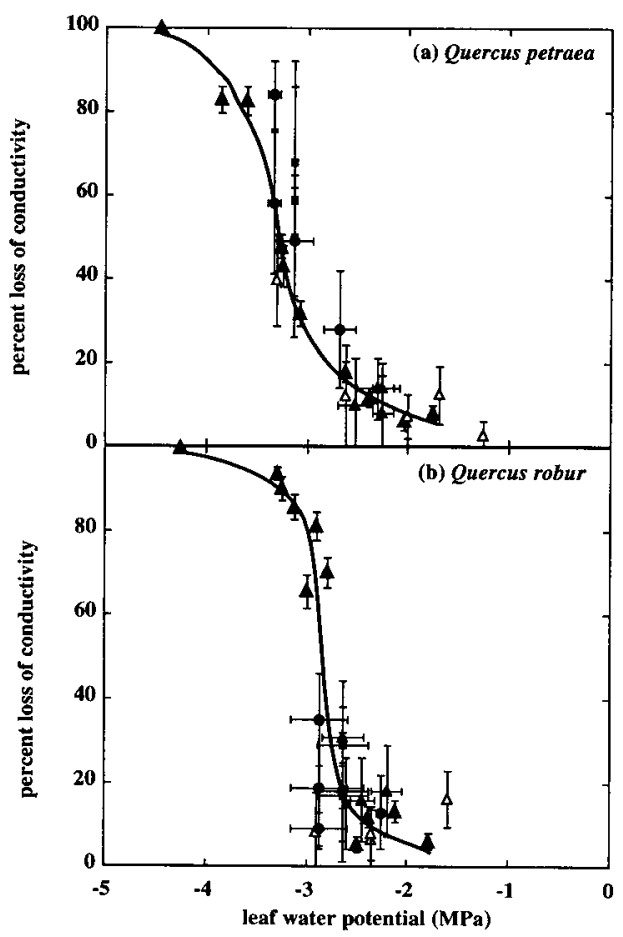

Fig 7. Comparison between vulnerability curves (large triangles) to cavitation for petioles of $Q$ petraea (a) and $Q$ robur (b) (data from Cochard et al, 1992) and losses of conductivity observed during in situ dehydration. Each symbol represents a different tree, open symbols are for the 1991 measurements. Bars are SD calculated on 5 to 8 replicates for hydraulic conductivity and 3 replicates for water potential.

agreed well with the vulnerability curve obtained in the laboratory.

\section{DISCUSSION AND CONCLUSION}

Although oak transpiration was reduced under drying soil conditions, it remained quite high even for $\psi_{\text {wp }} \leq-1.7 \mathrm{MPa}$ : it was reduced by $\approx 75 \%$ when water stress was 


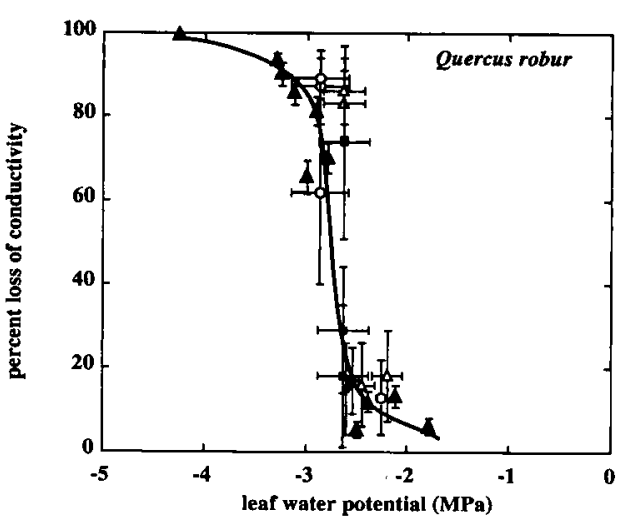

Fig 8. Comparison of corrected values of hydraulic conductivity losses with the vulnerability curve (large triangles) established under laboratory conditions on petioles of $Q$ robur, corrected values (open symbols) are calculated by using the pre-stress value of maximal hydraulic conductivity throughout the season.

maximum. We have shown in a recent paper (Bréda et al, 1993) that sessile oak was characterized by an efficient and deep root system. We concluded that $Q$ petraea was a rather drought-tolerant species because of its ability to maintain significant daily transpiration rates even under decreasing soil water availability.

Seasonal time-course of predawn leaf water potential showed a similar pattern during the $2 \mathrm{yr}$ of measurement: lower values were observed for sessile oak than for pedunculate during the periods of water shortage. We attributed this to a slightly higher transpiration rate in sessile than in pedunculate oaks. However, stomatal conductance was identical in both species. Higher sapflow in sessile oak could be explained by higher leaf area of individual trees. The total water extraction from $1.60 \mathrm{~m}$ depth was very similar in the vicinity of roots of pedunculate and sessile oaks. We also observed extraction from deeper layers near sessile oaks (160 to $200 \mathrm{~cm}$ ). These observations (higher leaf area and deeper soil water extraction) could help explain the slightly higher sapflow and lower $\psi_{w p}$ in the 3 individuals from this species that we observed. But these observed differences may not be an intrinsic species-related feature. Rather, they could be due to the favorable competitive status of the sessile oak individuals in mixed stands containing pedunculate oaks. This competitive advantage of $Q$ petraea vs $Q$ robur in mixed stands of 30-60 $\mathrm{yr}$ has frequently been reported by forest practitioners and ecologists (Lévy et al, 1992).

We did not find any difference in maximal stomatal conductance $\left(g_{\mathrm{s}}\right)$ between species in well-watered trees. Restricted water supply had a strong effect on stomatal conductance: $g_{\mathrm{s}}$ was reduced by $\approx 70 \%$ between -0.6 and $-2.0 \mathrm{MPa}$ predawn leaf water potential $\left(\psi_{\mathrm{wp}}\right)$, with no interspecific difference. On the other hand, no clear relationships between $g_{\mathrm{s}}$ and neither the radiation nor the vapor pressure deficit could explain the large dispersion of $g_{\mathrm{S}}$ between 0 and $-0.6 \mathrm{MPa}$. In fact, $\psi_{\text {wp }}$ seemed to be a poor indicator of stress intensity when soil began to dry out, because it could not help explain the early decrease in leaf stomatal conductance. Instead of $\psi_{\text {wp }}$, the soil water potential measured in the $30 \mathrm{~cm}$ upper soil profile, which contains $60 \%$ of the fine roots, would probably be a better characteristic to relate to $g_{\mathrm{s}}$. A recent hypothesis for stomatal regulation involves a hormonal signal from roots, which is influenced by soil water status. As reported by Schulze (1986) and Davies and Zhang (1991), soil water stress could trigger root signals stimulating stomatal reactivity. As a matter of fact, $\psi_{w p}$ may not represent the water potential in the driest soil layers, from where root signals could proceed, but probably of the wettest and deeper rooting layers. 
From this drought-induced course of stomatal conductance and total transpiration, we have concluded that the 2 studied species of oaks are water stress tolerant, and that no major difference between both exists under natural conditions.

However, under laboratory conditions, a difference in vulnerability to cavitation was observed between the species; $Q$ robur is more sensitive than $Q$ petraea (Cochard et al, 1992). Cavitation began when water potential reached $-2.2 \mathrm{MPa}$, and a $50 \%$ of embolism was measured at $-2.7 \mathrm{MPa}$ for $Q$ robur and $-3.2 \mathrm{MPa}$ for $Q$ petraea. We showed a good agreement between the \% loss of hydraulic conductivity measured under field conditions and those predicted by vulnerability curves when $K_{\max }$ was stable over the season. For pedunculate oak, we showed that $K_{\max }$ decreased, leading to an underestimation of the actual percentage of embolism. Two successive high pressure perfusions of samples did allow a complete dissolution of embolism (replaced the air by water) but the conductivity was not restored because of plugging of the vessels (tyloses, pit membrane occlusion, etc). The good stability of $K_{\max }$ between the first and the second flushes of high pressure reveals that air blockage of embolized vessels was not involved. The formation of tylosis as reported by Zimmerman (1979) that occurs in many trees at the end of the growing season and that occurs in $Q$ rubra and $Q$ alba (Cochard and Tyree, 1990) could presumably be responsible. A similar decrease in apparent $K_{\max }$ has been detected with potted saplings of $Q$ robur during increasing drought (Simonin et al, 1994).

If embolism is directly dependent on leaf water potential, then leaf water potential is strongly related to another characteristic of hydraulic function: the leaf specific conductivity (LSC) of the petiole, which is calculated as the ratio of $K_{\max }$ and the leaf area. The consequences of differing LSCs on leaf water potential and probability of cavitation occurrence have been discussed by Jones and Sutherland (1991). We observed a slight difference in LSC between species: $Q$ robur seemed to have lower LSC in petioles than $Q$ petraea (data not shown) which could increase its susceptibility to cavitation.

In spite of a difference in vulnerability, both species reached approximately the same levels of losses in hydraulic conductivity $(80 \%)$ under field conditions. In fact, dominant trees of $Q$ petraea had lower leaf water potentials. It is worth noting that stomatal conductance was significantly reduced at $\psi_{\mathrm{wp}}=-0.6 \mathrm{Mpa}$, corresponding to $\psi_{\mathrm{wm}}=-2.0 \mathrm{MPa}$. This value is also the threshold for which embolism can significantly increase. Maximum stomatal closure occurred when $\psi_{\text {wp }}=-1.5 \mathrm{MPa}$. At this time, $\psi_{\mathrm{wm}}=-3.0 \mathrm{MPa}$ and the loss of hydraulic conductivity is close to $30 \%$. Stomatal regulation was able to control the degree of embolism and to restrict it to this value for $\approx 1$ month, despite decreasing soil water availability. Later on, with greater drought, stomatal regulation was not able to prevent a sharp increase of embolism. Loss of conductivity reached $80 \%$ within a few $d$. Such a situation is in agreement with the model suggested by Tyree et al $(1988,1989,1991)$. It seemed surprising to us that such a large loss of conductivity in the petioles (and probably also in the youngest twigs) did not strongly affect the total sap flow of the trees. Total transpiration remained constant below $2.5 \mathrm{MPa}$. This may be an illustration of the fact that the main resistance to liquid water flow from roots to leaves is probably located between the soil-root interface and the branches. As a consequence, strong increases in the minor resistance like that in petioles or twigs have only limited consequences on the total resistance to water flow (Tyree et al, 1994). 


\section{REFERENCES}

Abrams MD (1990) Adaptations and responses to drought in Quercus species of North America. Tree Physiol 7, 227-238

Becker M, Lévy G (1982) Le dépérissement du chêne en forêt de Tronçais. Les causes écologiques. Ann Sci For 39, 439-444

Becker M, Lévy G (1986) Croissance radiale comparée de chênes adultes (Quercus robur $L$ et $Q$ petraea (Matt) Liebl) sur sol hydromorphe acide : effet du drainage. Acta $C E c o l$ CEcol Plant 7, 121-143

Bréda $N$, Cochard $H$, Dreyer $E$, Granier A (1993) Seasonal evolution of water transfer in a mature oak stand (Quercus petraea (Matt) Liebl) submitted to drought. Can J For Res 23, 1136-1143

Cochard H, Tyree MT (1990) Xylem dysfunction in Quercus: vessel sizes, tyloses cavitation and seasonal changes in embolism. Tree Physiol 6, 393-407

Cochard H, Granier A, Bréda N (1992) Vulnerability to air embolism of three European oak species (Quercus petraea (Matt) Liebl, $Q$ pubescens Will, $Q$ robur L). Ann Sci For 49 , 225-233

Davies WJ, Zhang J (1991) Root signals and the regulation of growth and development of plants in drying soils. Annu Rev Plant Physiol Plant Mod Biol 12, 55-76

Granier A (1985) Une nouvelle méthode pour la mesure de flux de sève brute dans le tronc des arbres. Ann Sci For 42, 193-200

Granier A (1987) Evaluation of transpiration in a Douglas-fir stand by means of sap flow measurements. Tree Physiol 3, 309-320

Jones $H G$, Sutherland RA (1991) Stomatal control of xylem embolism. Plant Cell Environ 14, 607-612

Lévy G, Becker M, Duhamel D (1992) A comparison of the ecology of pedunculate and ses- sile oaks: radial growth in the centre and North-West of France. For Ecol Manage 55, 51-65

Pardé L (1942) Le chêne pédonculé et le chêne rouvre dans les forêts du nord-est de la France. Rev Eaux For 80, 279-317

Poskin A (1934) Le chêne pédonculé et le chêne rouvre; leur culture en Belgique. Gembloux : Duculot, Librairie Agricole de la Maison Rustique, Paris, $223 p$

Schulze ED (1986) Carbon dioxide and water vapor exchange in response to drought in the atmosphere and in the soil. Annu Rev Plant Physiol 37, 247-274

Simonin G, Cochard H, Delatour C, Granier A, Dreyer $E$ (1994) Vulnerability of young oaks (Quercus robur) to embolism during water stress and after an inoculation with Ophiostoma querci. Ann Sci For (in press)

Sperry JS, Donnelly JR, Tyree MT (1988) A method for measuring hydraulic conductivity and embolism in xylem. Plant Cell Environ $11,35-40$

Tyree MT, Sperry JS (1988) Do woody plants operate near the point of catastrophic xylem dysfunction caused by dynamic water stress? Answers from a model. Plant Physiol 88, 574-580

Tyree MT, Sperry JS (1989) The vulnerability of xylem to cavitation and embolism. Annu Rev Plant Physiol Mol Biol 40, 19-38

Tyree MT, Ewers FK (1991) The hydraulic architecture of trees and other woody plants. New Phytol 119, 345-360

Tyree MT, Sinclair B, Lu P, Granier A (1994) Whole shoot hydraulic resistance in Quercus species measured with a new high-pressure flowmeter. Ann Sci For (in press)

Zimmerman MH (1979) The discovery of tylose formation by a Viennese lady in 1845. IAWA Bull (NS) 2-3, 51-56 